\title{
Lost in the Struggle: Aussie Battlers in the Rhetoric of Opposition
}

\author{
Joshua Bee
}

\section{Abstract}

This essay examines the role of the Aussie Battler in Australian political rhetoric. I argue that the Aussie Battler is a rhetorical incarnation of economic struggle, in which an Opposition utilises an ambiguity akin to dog whistling to foment and direct dissatisfaction towards an incumbent Government. Concepts like these are necessarily self-limiting after the Opposition deploying them is elected, as the circumstances from which they arise directly conflict with the expected rhetoric of competent and effective Government. Whilst particular incarnations of this rhetoric may hold partisan connotations, for instance Howard's Battlers or Rudd's Working Families, the pool of discontent they seek to foment and mobilise remains largely consistent. Curiously, this ongoing manipulation and promise of representation seems to undermine the essence of the Battler cultural ethic that makes identification with such articulations rhetorically significant.

\section{Introduction}

In 1988 John Howard, as Leader of the Opposition, gave a speech designed to foster a sense of disjuncture between the Government, and Australians who felt that - for a reason that perhaps was not entirely clear - life was harder than it should be. ${ }^{1}$ Over the next eight years, a shadowy horde of Aussie Battlers banded together against an elitist Government that was 'out of touch', and in 1996, 'Howard's Battlers' were widely credited with delivering Australia its first Liberal Government in over a decade. ${ }^{2}$ Whilst their significance as a construct necessarily diminished during the Howard years, the pool of potentialities from which the Aussie Battler arose remained. In the lead up to the 2007 election, this pool of alienation and struggle was reincarnated by Labor under Kevin Rudd, challenging Howard's incumbency on behalf of the 'Working Families'.

\footnotetext{
1 Commonwealth, Parliamentary Debates, House of Representatives, 29 September 1988, 1214 (John Howard, Leader of the Opposition). Retrieved from http://parlinfo.aph.gov.au/parlInfo/search/display/display.w3p;qu ery $=$ Id \%3A \%22 chamber \%2Fhansardr\%2F1988-09-29\%2F0119\%22 on 10/4/12.

2 Murray Goot and Ian Watson (2007): “Explaining Howard's Success: Social Structure, Issue Agendas and Party Support, 1993-2004", Australian Journal of Political Science, 42:2, 254.
} 
This essay will argue that the 'Aussie Battler' is a rhetorical incarnation of economic struggle, in which an Opposition utilises an ambiguity akin to dog whistling to foment and direct dissatisfaction towards an incumbent Government. Concepts like these are necessarily self-limiting once the Opposition deploying them is elected, as the circumstances from which they arise directly conflict with the expected rhetoric of competent and effective Government. Therefore, the 'Aussie Battler' is primarily a rhetorical tool for attacking incumbency, and can be reworked and deployed against its former masters, as illustrated by the rise of Labor's 'Working Families' and the downfall of the Howard Government.

\section{Identification through economic struggle}

'Aussie Battlers' and 'Working Families' can both be seen as rhetorical incarnations of economic struggle, intended to draw a wide and ambiguously defined identity. Examining Howard's speech in 1988, the identity is broadly bordered by two conceptions. The first pillar of battler identity is a perceived struggle to make ends meet, particularly as a result of interest rates and the cost of living (e.g. groceries, transport etc.).

Is [Keating] so out of touch that he does not recognise that in March 1983, when he became Treasurer of this country, the average family had to set aside 19.7 per cent of its weekly income to pay off its home and it now has to set aside 27.7 per cent of its weekly income to pay off its home? Is he so out of touch that he does not realise that in March 1983 an average wage earner had to work 33 weeks to buy the Australian family car and now has to work 49 weeks to buy that same family car?... If any of them dared to go into the supermarkets of Australia...they would find that the people in those parts of Australia know that family living standards have fallen. ${ }^{3}$

The terminology used in the construction of this identity has significant parallels with dog whistle politics, in that the use of ambiguous but culturally positive language makes the identity accessible to voters who may otherwise be split along various demographic lines. ${ }^{4}$ Dog whistling refers to the use of ambiguous, 'coded' words, to alter the impact a statement will have on different audiences, whilst minimising negative ramifications for the speaker. ${ }^{5}$ As Fear argues, the language chosen seeks to "enlighten a select audience while keeping

3 Howard (1988), Parliamentary Debates.

4 Josh Fear (2007): “Under the Radar: Dog-whistle politics in Australia", The Australia Institute, Discussion Paper Number 96, 5. Retrieved from https://www.tai.org.au/file.php?file=discussion_papers/DP96.pdf on 25/4/12.

5 Ibid 
others in the dark as to its real meaning". ${ }^{6}$ The rhetoric of the 'Aussie Battler' or the 'Working Family' utilises a comparative ambiguity, which appeals to a much wider audience than would be the case if the identity was forged around explicit demographic markers. ${ }^{7}$

The term 'Aussie Battler' refers to an individual who represents a quintessentially Australian stoicism and determination. In a harsh landscape, the Aussie Battler struggles without pretention, and in so doing is glorified in the Australian psyche. ${ }^{8}$ As has been seen above, Howard's Aussie Battlers' landscape is one defined primarily, though not exclusively, by economic hardship. The cultural significance of this framing and the ambiguous borders of its potential membership encourage a broad audience to find resonance in the identity, despite vastly different economic circumstances.

This is illustrated most succinctly by the rise of the pejorative "middle-class battler" in academia, describing those who feel they are struggling to subsist, whilst in fact they are relatively well off. ${ }^{9}$ However, by deliberately defining 'Aussie Battlers' and 'Working Families' in broad terms rather than strict social markers - as those who feel pressured by interest rates or as those who now have to pay more for a 'family car' - speakers such as Howard are able to tie together a markedly diverse populace. Having done so, this perceived struggle is defined as a consequence of the actions of an out of touch and elitist Government, thereby creating the second pillar of Battler identity.

\section{The Government as the antagonist}

Whilst the rhetorical victims are drawn broadly, the antagonist is narrowly defined as the Government, and an ambiguity akin to dog whistling is employed to covertly amplify its disjuncture with the audience. This is illustrated in Howard's speech by aggrandising the Government's role in setting interest rates relative to the Reserve Bank.

\footnotetext{
6 (Emphasis original) Ibid.

7 Whilst I shall not examine coding in detail here, it is not unreasonable to assume that these terms may have a particular meaning for certain segments of the community that may vary with the assumptions held by the audience. For instance, Aussie Battler may have particular connotations for those concerned about immigration, and Working Families may have particular connotations for social conservatives, particularly in a period when same-sex marriage was gaining increasing exposure.

8 "Meanings and origins of Australian words and idioms - 'battler"', Australian National Dictionary Centre (online). Retrieved from http://andc.anu.edu.au/australian-words/meanings-origins?field_alphabet_value=71 on $19 / 4 / 12$.

9 Clive Hamilton (2002): "Overconsumption in Australia: The rise of the middle-class battler", The Australia Institute, Discussion Paper Number 49, 1. Retrieved from https://www.tai.org.au/file.php?file=discussion papers/DP49.pdf on 19/4/12.
} 
As this debate commences, the drover's dog is winging his way overseas and the clink of the first-class drinks trolley can be heard... if the Treasurer dared to jump out from behind the tinted glass of his Sydney car, if he dared to go back to Bankstown - and I doubt whether he could get there without the aid of a Gregory's street directory - they would find that the people in those parts of Australia know that family living standards have fallen...interest rates will go up as a result of the economic policies of this Government. ${ }^{10}$

Depending on the preoccupations of the listener, his descriptions of the Government's overseas engagement - and of Keating behind the "tinted glass of his Sydney car"- may appeal, as Greenfield and Williams argue, to the resentment of "cosmopolitan new class elites" amongst sections of the community in the period. ${ }^{11}$ It may also appeal to the notion of a wasteful Government, or just come across as a simple taunt, inconspicuous in the back and forth of daily politics to those who cannot otherwise relate to the concerns of the Opposition. Alienation from the incumbent Government was fomented by Rudd's 2007 campaign in a similar fashion. By subtly commenting on Howard's opportunities and rhetoric to suggest he only had the interests of his friends, big business, and mining companies at heart as opposed to 'Working Families', whilst ostensibly merely highlighting that he has 'lost touch', Rudd was able to create a level of unity whilst still capitalising on potentially divisive issues amongst sympathetic listeners. ${ }^{12}$ The pivotal role this sense of alienation plays in the formulation of 'Aussie Battlers' characterises the concept as a tool of the Opposition.

\section{Demise and reincarnation}

The shelf-life of a particular incarnation of the 'Aussie Battler' is limited as the circumstances from which it arises directly conflict with the expected rhetoric of competent and effective Government. As Dyrenfurth argues, Battlers should not be battling long after their champion has been elected. ${ }^{13}$ That both Governments and Oppositions are aware of this fact is illustrated by an examination of the invocation of 'Aussie Battlers' and 'Working Families' in the Parliament. The following data was retrieved from analyses of online Parliamentary

10 Howard (1988), Parliamentary Debates.

11 Cathy Greenfield and Peter Williams (2001): “'Howardism' and the media rhetoric of 'Battlers' vs 'Elites'”, Southern Review (Adelaide), 34:1, 32.

12 Australian Labor Party, "Really Mr Howard?", www.youtube.com (3 November 2007). Retrieved from http://www.youtube.com/watch?v=IglwqumUQtU\&feature=relmfu on 19/4/12.

13 Nick Dyrenfurth (2008): “Who are the 'working families'?", www.onlineopinion.com.au. Retrieved from http://www.onlineopinion.com.au/view.asp?article=7060\&page $=0$ on 25/4/12. 
Collections, and is presented in Table $1 .{ }^{14}$ From 1990 to the change of Government in 1996, there was a fourfold increase in the invocation of the 'Aussie Battler' by the Liberal Party compared to the prior two Parliaments, sitting from 1985 to 1990. Whilst Labor's use of the term also increased notably in 1995, this is primarily in an attempt to refute the Opposition's rhetoric, and, as Senator Jacinta Collins argued, to give "a much fairer comparison of where Australia stands with respect to its treatment of the Aussie battler". ${ }^{15}$ A comparable increase occurs with 'Working Families' in the lead up to the 2007 election which resulted in a change from the Howard to the Rudd Government.

The two Parliaments preceding the change of Government, sitting from 2002 to 2007, saw a dramatic increase in Labor's invocation of 'Working Families' when compared to the two previous, sitting from 1996 to 2001. As per Table 1, preceding the change of Government, Labor's invocations rose from an average of 59 per year from 1996 to 2001, to 157 in 2002-2004, and then 303 in 20042007. What both the Howard and the Rudd change of Governments illustrate is a general trend in which rhetoric surrounding economic struggle increases directly in the lead up to and immediately following instances of change. These figures also demonstrate that the rhetoric of economic struggle may quickly become a liability for a new Government.

Following Howard's victory - particularly noticeable in the 39th and 41st Parliaments (1998-2001 and 2004-2007 respectively) - most references to the Liberal's 'Aussie Battlers' were made by Labor, whereas the Liberal Party's invocation returned quickly to their pre-rise levels. This trend appears to be recurring following the 2007 change of Government. As shown in Table 1, the Liberal Party's invocation of 'Working Families' rose from 55 instances in 20042007, to 481 instances in 2008-2010. Labor's use of the term also rose dramatically in 2008-2010. Research into the causes of this rise warrant deeper examination than can be provided here, particularly given the leadership challenge that occurred during this period. However, following this rise, Labor's invocation of 'Working Families' in the current Parliament under Gillard has again dropped, with just under half of all references having been made by the Opposition. ${ }^{16}$ Whilst it remains to be seen whether the figures remain stable, this supports the theory of the limited shelf-life of 'Working Families' in Government. A comparison of Howard's rhetoric in 1988 with that utilised by the Labor

14 All data was retrieved from the Parliamentary Collections online search engine, limiting results to the House of Representatives and the Senate: http://parlinfo.aph.gov.au/parlInfo/search/search.w3p;adv=yes There is some discrepancy in the results between the total number of debates mentioning the term 'Working Families' and the recorded usage by party.

15 See, for example Commonwealth, Parliamentary Debates, Senate, 30 November 1995, 4442 (Senator Jacinta Collins, Victoria). Retrieved from http://parlinfo.aph.gov.au/parlInfo/search/display/display.w3p;qu ery $=\mathrm{Id} \% 3 \mathrm{~A} \% 22$ chamber $\% 2 \mathrm{Fhansards} \% 2 \mathrm{~F} 1995-11-30 \% 2 \mathrm{~F} 0199 \% 22$ on 30/9/12.

16 As of 25/4/2012, there were 130 Opposition references compared to 167 by the Government. 
The ANU Undergraduate Research Journal

Party in 2007 supports the notion that that particular identities, such as 'Aussie Battlers' and 'Working Families' are in fact rhetorical incarnations arising from largely the same pool of potentialities.

\section{Working families are Aussie Battlers}

In 2007, Labor released a series of ads seizing on Howard's declaration that "Working families in Australia have never been better off". ${ }^{17}$ Decrying high interests rates, costs of living, and employment conditions, 'Working Families' emphasised that Howard had lost touch with the experiences of the wider community:

My child care and grocery prices are higher than ever, we're working longer and harder under Work Choices, and those interest rate rises, they've stretched us to the limit. Imagining these kids owning their own homes is just a joke. Never better off? You've lost touch Mr Howard. No offence, but you've just been there too long. ${ }^{18}$

If one was to strip the explicit mention of Work Choices, any façade of distinction between Aussie Battlers and Working Families is lost when trying to determine the target of the mocking derision: "our priorities are right; there is nothing to worry about". ${ }^{19}$ The 2007 campaign is a near replica to the appeal to interest rates, cost of living, and alienation - particularly as a result of the length of incumbency, which Howard made in 1988:

The reality is that this Government has been in power so long that it has grown arrogant and indifferent. It has lost touch with ordinary Australians and increasingly it has no idea of the life and the circumstances of average families. ${ }^{20}$

Arguably what this indicates is that, whilst particular incarnations such as 'Aussie Battlers' or 'Working Families' may have partisan connotations, these identities are in fact activated through a rhetoric which is fundamentally based on a common sense of economic alienation from Government. As such, these incarnations must primarily be seen as a rhetorical tool for attacking incumbency, which may reforged and deployed against its former masters.

In all, this appears to paint a rather bleak picture for the future of 'Aussie Battlers'. Implicit in all of the appeals to champion their cause is the notion

17 Christine Jackman (2008), Inside Kevin 07: The People. The Plan. The Prize. (Melbourne University Press; Carlton) 103-105.

18 Australian Labor Party, “Really Mr Howard?".

19 Howard (1988), Parliamentary Debates.

20 ibid. 
that they should not be struggling, and the promise of easier days under a new Government. The difficulty of delivering such a promise - having cast the identity so wide - is that it is more or less inevitable that a significant portion of the diverse population rallied will be disappointed, a new sense of alienation will accrete, and the cycle will continue. The quintessentially Aussie Battler who struggles without pretention, and in so doing is glorified in the Australian psyche, ${ }^{21}$ has, in a sense, become lost in the struggle of the 'Aussie Battler'. Whereas such an identity previously provided a level of introspective comfort in the face of the harsh realities of economic survival, it remains to be seen whether or not Australians will be able to arrive at a level of contentment without addressing the political manipulation of their material circumstances.

\section{References}

Australian Labor Party, "Really Mr Howard?", www.youtube.com (3 November 2007). Retrieved from http://www.youtube.com/watch?v=IglwqumUQtU\&f eature $=$ relmfu on $19 / 4 / 12$.

Commonwealth, Parliamentary Debates, House of Representatives, 29 September 1988, 1214 (John Howard, Leader of the Opposition). Retrieved from http:// parlinfo.aph.gov.au/parlInfo/search/display/display.w3p;query $=\mathrm{Id} \% 3 \mathrm{~A} \% 2$ 2chamber\%2Fhansardr\%2F1988-09-29\%2F0119\%22 on 10/4/12.

Commonwealth, Parliamentary Debates, Senate, 30 November 1995, 4442 (Senator Jacinta Collins, Victoria). Retrieved from http://parlinfo.aph.gov. au/parlInfo/search/display/display.w3p;query=Id \%3A \% 22 chamber \% 2Fha nsards\%2F1995-11-30\%2F0199\%22 on 30/9/12.

Dyrenfurth, N. (2008): "Who are the 'working families'?", www.onlineopinion. com.au. Retrieved from http://www.onlineopinion.com.au/view. asp ?article $=7060$ \&page $=0$ on $25 / 4 / 12$.

Fear, J. (2007): "Under the Radar: Dog-whistle politics in Australia", The Australia Institute, Discussion Paper Number 96, 5. Retrieved from https:// www.tai.org.au/file.php?file=discussion_papers/DP96.pdf on 25/4/12.

Greenfield, C. and Williams, P. (2001): “'Howardism' and the media rhetoric of 'Battlers' vs 'Elites'”, Southern Review (Adelaide), 34:1, 32.

21 "Meanings and origins of Australian words and idioms - 'battler", Australian National Dictionary Centre (online). Retrieved from http://andc.anu.edu.au/australian-words/meanings-origins?field_alphabet_value=71 on $19 / 4 / 12$. 
Goot, M. and Watson, I. (2007): “Explaining Howard's Success: Social Structure, Issue Agendas and Party Support, 1993-2004" , Australian Journal of Political Science, 42:2, 254.

Hamilton, C. (2002): "Overconsumption in Australia: The rise of the middle-class battler", The Australia Institute, Discussion Paper Number 49, 1. Retrieved from https://www.tai.org.au/file.php?file=discussion_papers/DP49.pdf on $19 / 4 / 12$.

Jackman, C. (2008), Inside Kevin 07: The People. The Plan. The Prize. (Melbourne University Press; Carlton) 103-105.

"Meanings and origins of Australian words and idioms - 'battler"", Australian National Dictionary Centre (online). Retrieved from http://andc.anu.edu.au/ australian-words/meanings-origins?field_alphabet_value=71 on 19/4/12. 
Lost in the Struggle: Aussie Battlers in the Rhetoric of Opposition

\begin{tabular}{|c|c|c|c|c|c|c|c|c|c|c|c|}
\hline & $\bullet$ & $N$ & $\sim$ & $N$ & गิ & 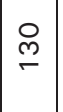 & $\hat{\theta}$ & $\overline{5}$ & $\stackrel{\dot{0}}{\frac{1}{2}}$ & 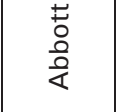 & $\begin{array}{l}\overline{0} \\
\frac{0}{0} \\
\overline{\bar{\sigma}}\end{array}$ \\
\hline & $\theta$ & $N$ & $\sim$ & & 암 & $\begin{array}{c}\bar{\infty} \\
+\end{array}$ & $\underset{\infty}{\stackrel{M}{O}}$ & $\begin{array}{l}\mathscr{E} \\
\mathscr{O}\end{array}$ & ó & 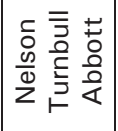 & $\begin{array}{l}\frac{0}{0} \\
\frac{0}{2} \\
\frac{1}{4}\end{array}$ \\
\hline & $\theta$ & & $\nabla$ & & के & \begin{tabular}{|l|} 
\\
\end{tabular} & ֻે & $\stackrel{\leftrightarrow}{\sim}$ & 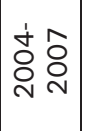 & 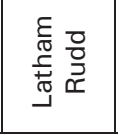 & 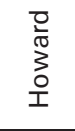 \\
\hline & $\Lambda$ & $m$ & $N$ & $N$ & $\overline{\bar{N}}$ & ০ & $\stackrel{ }{\circ}$ & $\approx$ & 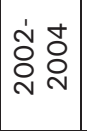 & 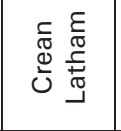 & 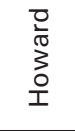 \\
\hline & $\wedge$ & $N$ & $\nabla$ & - & ญै & $\mathbb{N}$ & $\stackrel{\infty}{m}$ & $N$ & ó & 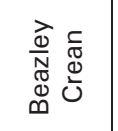 & 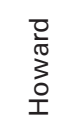 \\
\hline & ๑) & $\nabla$ & $N$ & $m$ & 5 & $\stackrel{m}{-}$ & 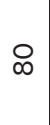 & $\nabla$ & 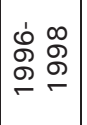 & $\begin{array}{l}\frac{\vec{d}}{N} \\
\mathbb{\varpi} \\
\infty \\
\infty\end{array}$ & 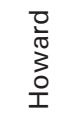 \\
\hline & $m$ & $\wedge$ & م & - & 요 & t & $\pi$ & $\stackrel{m}{-}$ & 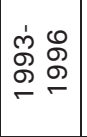 & 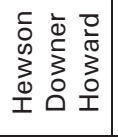 & 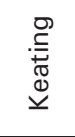 \\
\hline & $m$ & $\infty$ & $\sim$ & $m$ & $\bar{\sigma}$ & م & $\stackrel{m}{\forall}$ & $\infty$ & 호 & 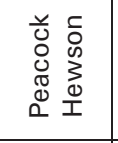 & 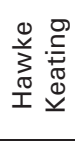 \\
\hline & $\wedge$ & $N$ & $m$ & $N$ & के & $\stackrel{0}{-}$ & $\mathscr{8}$ & $\sigma$ & 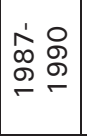 & 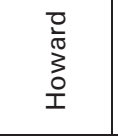 & 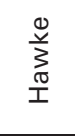 \\
\hline & $m$ & $N$ & & - & 음 & $N$ & 0 & $N$ & 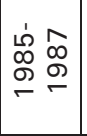 & 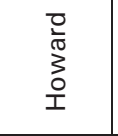 & 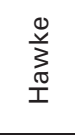 \\
\hline & $\bullet$ & مـ & & - & $\infty$ & $\theta$ & $\nabla$ & & 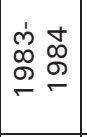 & 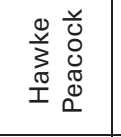 & 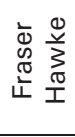 \\
\hline & $m$ & - & - & - & 음 & $\theta$ & 0 & & \begin{tabular}{ll}
0 & 0 \\
$\infty$ & $\infty$ \\
$o$ & $\infty$ \\
\hdashline & 0 \\
-
\end{tabular} & $\begin{array}{l}\frac{c}{d} \\
\frac{0}{0} \\
\frac{\pi}{I}\end{array}$ & 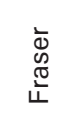 \\
\hline & 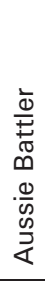 & $\begin{array}{l}\bar{\sigma} \\
\bar{d} \\
\stackrel{0}{\Xi} \\
\end{array}$ & $\begin{array}{l}\grave{a} \\
\stackrel{0}{\pi} \\
\end{array}$ & 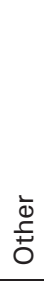 & 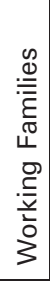 & \begin{tabular}{|l|}
$\bar{\sigma}$ \\
$\overline{0}$ \\
$\stackrel{0}{\Xi}$ \\
\end{tabular} & $\begin{array}{l}\grave{0} \\
\stackrel{0}{\sigma} \\
\unlhd\end{array}$ & 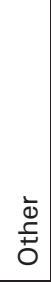 & & 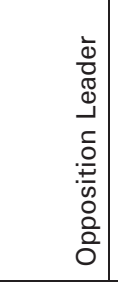 & 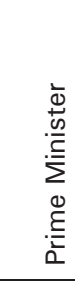 \\
\hline
\end{tabular}

